\title{
CURRENT STATUS OF CUT FLOWER BUSINESS IN NEPAL
}

\author{
D. P. Gauchan*, Anaya Raj Pokhrel, Manish Pratap, Prabesh Lama \\ Department of Biotechnology \\ Kathamandu University, Dhulikhel, NEPAL \\ *Corresponding author: gauchan@ ku.edu.np
}

Received 01 September, 2008; Revised 02 January, 2009

\begin{abstract}
In this article an attempt has been made to cover all the aspects of cut flower business including the present scenario, prospects and different factors which need to be improved in order to meet the expected standards. This report offers the information regarding the status of current market, area of production and demands of different cut flowers such as carnation, gerbera, gladiolus and rose in Nepalese market, which facilitates persons to make up their mind to figure out the floriculture business in Nepal. Cut flower business has flourished in Nepal compared to yesteryears, but the development is not sufficient to fulfill the demand of consumers. The production decreases during the winter season in comparison to summer season. This article also includes list of numbers of producers, their position in the market and the situation of consumer. The export and import data of few years has also been illustrated. It gives the brief information regarding annual production of these flowers, present price per stick and its demand in domestic and international market.
\end{abstract}

Key words: Cut flower, gladiolus, carnation, gerbera, rose, floriculture

\section{INTRODUCTION}

Floriculture is the discipline of horticulture, which refers to the cultivation of ornamental plants, flowering plants, foliage plants, cut flowers, bulbs, seeds and seedlings. Floriculture is fast emerging as a booming industry in the global context but it is relatively in a premature phase in Nepal. Cut flowers are parts of plants, characteristically including the blooms or inflorescences and some attached plant materials, but not including roots and soil. Fresh cut flowers are used for decorative purposes such as vase arrangements and bouquets at formal events; designs for weddings and funerals; gifts on occasions such as Mother's Day, Valentine's Day and in times of illness.

Nepal is rich in biodiversity having 6500 species of flowers, bushes and trees blooming in the uphill of the Himalayas to Terai. Due to the favorable climate, cheap labor, and suitable soil floriculture can be one of the prominent enterprises especially in hills and inner plains. For the promising development of floriculture the cut flower has played significant role in Nepal. Cut flower is an emerging business having a short history in Nepal. It started from Kathmandu and expanded to cities like Biratnagar, Dharan, Chitwan and Pokhara. For the upliftment of the cut flower and for the promotion of its business the FAN (Floriculture Association of Nepal) was established in collaboration with AEC (Agro-enterprises Centre) in 15th November 1992 with 10 founder members from nurserymen and people interested in floriculture at the C.D.O. office of Lalitpur district. FAN now having 208 members from all over Nepal. The floriculture wholesale market was established in August 31, 1998 by FAN. 
The number of nurseries has increased from 80 to 550 and the number of floriculture shops/retailers increased from 5 to 58 from 1992 to 2008. The volume of floriculture business in Nepal is growing at the rate of 10-15 percent a year. Today, the sector employs more than 2500 people with more than 60 percent women employees. This sector has already fetched investment over NRs. 375 million in infrastructure and planting materials. Although Nepal started exporting floral products just a few years back, its reach has gone up from India, USA, Japan, the Netherlands, Norway, Australia, Taiwan, Italy, Germany and some of the Gulf countries (Shrestha, 1999).

In Nepal, the major cut flowers that are produced to fulfill the market demand are categorized as following:

1. Throughout year production: (production is all the time); Gerbera, Rose, Carnation, and Gladiolus.

2. Seasonal production: (production is more than three months in a year); Chrysanthemum, Tuberose and Birds of paradise.

3. Yearly production: (production is only once in a year in a defined time); Amarlies, Antirrhinum, Asrtromeria, Calla, Celocia, Chincherinchee and Daffodils.

\section{MATERIALS AND METHODS}

The study was carried out from December, 2007 to December, 2008 in Kathmandu valley. Data required for carrying out this study were obtained from both primary and secondary sources. Information on the technical and agronomic requirements of cut flower, popular varieties, location and trade situation were obtained from secondary sources by reviewing related literature on floriculture and from the official records of FAN and Trade Promotion Centre. Data were collected in two ways: review of related literature and dissemination of questionnaires among people involved in different aspects of cut flower business. Various questionnaires were prepared and interviewed people who actively engaged in this business.

During these visits the information was collected for knowing the status of cut flowers like Gladiolus, Gerbera, Rose and Carnation. Nurseries, wholesalers and different retailer shops were visited and information was gathered from personal interviews. Information regarding the trade of our country regarding floriculture was recorded from Trade Export Promoting Centre (TEPC).

\section{MARKET ANALYSIS}

\section{World Scenario}

The annual consumption of cut flowers in the world is worth US\$13,000 million. The main importers of cut flowers are the USA, Germany, France, UK, Switzerland, Sweden, Norway, the Netherlands, Denmark, Belgium, Italy, Australia, and Japan. Germany is the largest importer now, followed by the US, France and Britain. Among the exporters of cut flowers, the Netherlands dominates the world trade (65\%), followed by Columbia (12\%) and Israel (6\%). Thailand is world's sixth largest exporter of cut flowers (Prasad and Kumar, 2005). At present western Europe alone consumes half of the flowers produced in the world and a large expansion in flower consumption is taking place in Eastern Europe, Japan, China, South Korea, Thailand and Indonesia. 


\section{National Scenario}

Cut flower business has been centralized in the Katmandu valley. This localization is mainly due to access to consumer-orientation and favorable natural conditions. By and large, the establishment of such industries takes place wherever consumers with sufficient purchasing powers are living. The existence of most of the hotels, big business houses and international houses helps to encourage the establishment of these industries in Kathmandu rather than in other places. Similarly, the topological and climatic conditions prevalent within the valley support the establishment of floricultural enterprises (Chhetri, 1999). Cut flower business has shown steady and continuous development in Nepal. Due to urbanization and modernization, the demand of the cut flower has increased tremendously. In view of unmet demand for cut flowers, there is ample scope for promotion of this business within Kathmandu valley. Promotion of domestic production is expected to substitute cut flowers imported by hotels and other consumers, from India.

Production of cut flower has been categorized into two seasons i.e., summer season and winter season. In summer season, the demand of flower has been fulfilled by the Nepalese grower whereas in winter, wholesalers/retailers import flowers from India, as demand is not achieved by the Nepalese production. During the summer, the demand of the cut flower is accomplished by the production within Kathmandu, Bhaktapur, Lalitpur. Although during winter season the maximum demand is fulfilled from production of Terai (Table: 2). According to the quantity of production, the districts of Nepal could be divided into four categories: Group A, B, C and D (Table: 1).

Table 1: Cut flower production at district level

\begin{tabular}{|l|l|}
\hline Group & District \\
\hline A & Kathmandu, Bhaktapur, Lalitpur, Dhading, Chitwan, Makwanpur \\
\hline B & Jhapa, Morang, Sunsari, Dhanusha, Siraha, Kaski \\
\hline C & Dolakha, Banke, Kailali, Kanchanpur, Doti, Dadeldura \\
\hline D & $\begin{array}{l}\text { Ilam, Dhankuta, Saptari, Gorkha, Sindhupalchowk, Udayapur, Bara, } \\
\text { Parsa, Kapilbastu, Bardia. Nuwakot, Sarlahi, Rupandehi, Mahottari } \\
\text { Tanahu, Palpa }\end{array}$ \\
\hline
\end{tabular}

Source: FAN

Carnation, Gerbera, Gladiolus and Rose are the flowers which are produced and have enormous demand throughout the year.

Table2: Effect of temperature on production of cut flowers on different region

\begin{tabular}{|l|l|l|}
\hline Temperature & Kathmandu & Terai \\
\hline High & High production & Low production \\
\hline Low & Low production & High production \\
\hline
\end{tabular}

Source: Field Survey

\section{AGRO ECONOMIC ASPECTS}

\section{Carnation}

Carnation (Dianthus spp) belongs to the family Caryophyllaceae. Carnations are flowers which are widely recognized by most people. It means "flower of love" or "flower of the 
gods". There are approximately 300 species in the genus. They are native to the Eastern Hemisphere and are found naturally in the Mediterranean region, although modern varieties are grown both in greenhouses and in fields around the world. With such widespread commercial production available, there is no limited season of availability. Because of their long lasting qualities and fragrance, carnations are often featured in arrangements at holidays celebrated with flowers, at special occasions such as weddings and parties, and in sympathy arrangements.

There are several types of Carnations such as chabaud/margueriate, border and picotee, malmsison and perpetual flowering. But in Nepali market two types of carnation are popular, those are standard and spray. The demand of the carnation flower is 1,000-1,500 sticks per day. It can be cultivated around 8,000-9,000 plants in a ropani. It is estimated that there is production of 6.5 lakhs stick per annum (Table: 3). Kumari Fresh flower and Flora Nepal Pvt. Ltd. are the renowned producers of carnation (FAN, 2007).

\section{Gladiolus}

Gladiolus (Gladiolus spp) belongs to family Iridaceous. This large group consists of about 250 to 300 species of gorgeous, tender perennial corms, which are mainly natives of South Africa, although some are found wild in west and central Europe, the Mediterranean to southwest and central Asia, and northwest and east Africa. The name Gladiolus is Latin for small sword and refers to the shape of the leaves, thus these plants have been commonly called Sword Lilies and Corn Lilies.

There are different types of Gladiolus available in the Nepali market such as American Beauty, Berlew, Bush balland, Camalton etc. In market two types of Gladiolus i.e. single and double are widely available. The demand of the Gladiolus is 3,500-4,500 sticks per day. It can be cultivated around 10,000-120,000 plants in a ropani. Around 800,000 sticks per annum are produced. It is estimated that 340 ropani is being used for cultivation (Table: 3). It is the largest grown cut flower in Nepal which occupies the top position with $70 \%$ of all sales (Devtech, 1995).

\section{Gerbera}

Gerbera (Gerbera spp) belongs to the family Asteraceae. These herbaceous plants are found in South Africa. The fuzzy leaves grow in a rosette close to the soil and are lanceshaped, deeply lobed and about 12 inches long. During the summer, these plants bear many orange-scarlet flowers that resemble daisies atop a long stalk. Generally two types of gerbera i.e., single and double are found in Nepali market. Its demand is around 1,5002,500 sticks per day. Around 3,000 plants can be grown per ropani. It is estimated that 630,000 per sticks per annum is supplied by domestic producers (Table: 3). Bagmati Flora, Kumari Flora and Garden Service are the major producers.

\section{Rose}

Rose (Rosa indica) belongs to the family Rosaceae. It is the most popular garden plant in the world, as well as the most important cut flower. There are between 150 and 200 species of wild roses in the Northern Hemisphere, selection and hybridization has given rise to over 20,000 cultivars. It is highly valued for its form, fragrance and endless variety of color. 
Dutch Rose and Local Rose are most popular varieties available in the market. The demand of Rose is 2,500-4,000 sticks per day. It is estimated that 500,000 rose sticks per annum are produced and around 3,000 plants can be cultivated in a ropani (Table: 3 ). Everest nursery is the largest producer of Rose and only one to export to Japan.

Table 3: Demand and production of cut flowers

\begin{tabular}{|l|r|}
\hline Description & Estimated Data of 2007/2008 \\
\hline Carnation Demand (sticks/day) & $1000-1500$ \\
\hline Carnation production(in ropanies) & $8000-9000$ \\
\hline Carnation production per annum in(sticks) & 650000 \\
\hline Gladiolus Demand(sticks/day) & $3500-4500$ \\
\hline Gladiolus production(in ropanies) & $1000-120000$ \\
\hline Gladiolus production per annum in(sticks) & 800000 \\
\hline Gerbera Demand(sticks/day) & $1500-2500$ \\
\hline Gerbera production(in ropanies) & 3000 \\
\hline Gerbera production per annum in(sticks) & 630000 \\
\hline Rose Demand(sticks/day) & $2500-4000$ \\
\hline Rose production(in ropanies) & 3000 \\
\hline Rose production per annum in(sticks) & 500000 \\
\hline
\end{tabular}

Source: Field survey

\section{Producer}

There are altogether 550 nurseries in Nepal, out of which around 100 are involved in cut flower production. There are no authentic data that exhibit the exact number of farmers involved in cultivation of flowers (FAN, 2008). Authors identified the four major producers who are involved in production of cut flowers and who provide continuous supply of products to fulfill market demands (Figure: 1,2).

a. Flora United: It is established in 2008. It possess highest number of producers (around 30-45). It also covers highest percentage (35-45) of supply in total market.

b. Flora Incorporation: It was established in 2003, and has the second highest number of producers, (25-30). It covers 32-40 percentage of total market.

c. Flora Nepal Pvt. Ltd.: It covers 10-15 percentages. It produces only Carnation and Rose.

d. Standard nursery: Established in 1973, it cultivates Carnation, Gerbera and Gladiolus. It is producer as well as retailer. 
Figure1: Status of cut flower producers

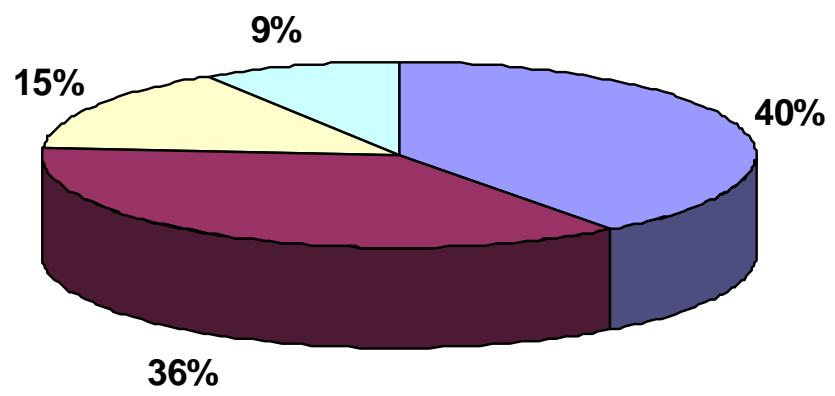

Flora United $\square$ Flora Incorporated $\square$ Flora Nepal pvt. Ltd. $\square$ Others

Source: Field survey

Figure 2: Wholesale market value (NRs.) of cut flower per stick

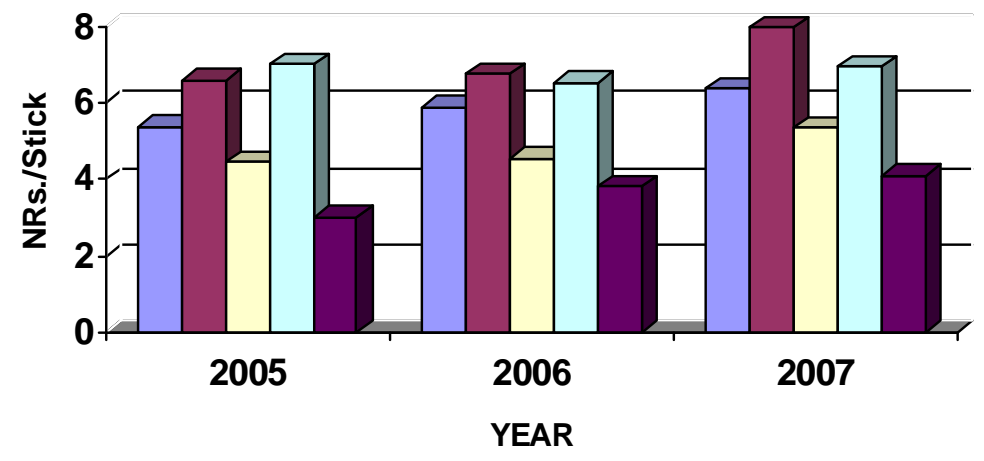

Carnation $\square$ Gerbera $\square$ Gladiolus $\square$ Dutch Rose $\square$ Local Rose

Source: Field survey

\section{Retailer}

Retailers are the people who sale goods or commodities in small quantities directly to consumers. The products are bought from wholesalers generally but they also get from nurseries/growers or they import through personal contacts at the time of low production in winter season.

Women in Floriculture, Chameli and Bodhi Brikchya were the first few retailers of the cut flower in Nepal. They were established in early 1990's. There were four retailers 
during the start of the cut flower business but, today the number has reached to 58 . Daffodil, Florist, Women in Floriculture, Design and Bagmati flora are the some of the major retailers. Generally gift-shops and departmental stores function as retailers to sell cut flowers. These retailers are confined to commercial areas of Kathmandu valley such as Tripureshwor, Chabahil, Pulchowk, Kamalpokhari, Maharajgunj, Kupandole and Paknajol (Anonymous, 2002). Figure: 3 and table: 4 show the market price of cut flower (per stick) in retailers shop in different years.

Figure 3: Retailer market value (NRs.) of cut flower per stick

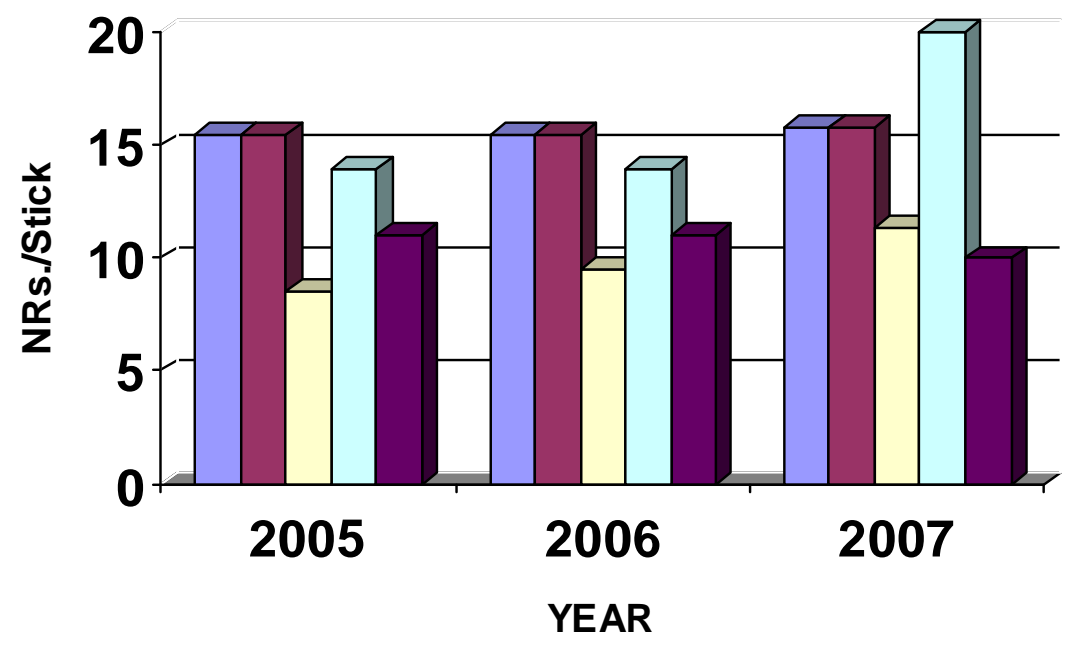

\section{$\square$ Carnation $\square$ Gerbera $\square$ Gladiolus $\square$ Dutch Rose $\square$ Local Rose}

Source: Field survey

Table 4: Wholesale and retailer market value of cut flowers during (2005-2007)

\begin{tabular}{|c|c|c|c|c|c|c|}
\hline \multirow[t]{2}{*}{ Flower } & \multicolumn{3}{|c|}{$\begin{array}{l}\text { Whole sale price } \\
\text { (NRs/stick) }\end{array}$} & \multicolumn{3}{|c|}{$\begin{array}{l}\text { Retailer price } \\
\text { (NRs/stick) }\end{array}$} \\
\hline & 2005 & 2006 & 2007 & 2005 & 2006 & 2007 \\
\hline Carnation & 5.37 & 5.87 & 6.35 & 15.5 & 15.5 & 15.83 \\
\hline Gerbera & 6.58 & 6.75 & 7.96 & 15.5 & 15.5 & 15.83 \\
\hline Gladiolus & 4.45 & 4.54 & 5.35 & 8.5 & 9.5 & 11.33 \\
\hline Dutch Rose & 7 & 6.53 & 6.93 & 14 & 14 & 20 \\
\hline Local Rose & 3 & 3.81 & 4.08 & 11 & 11 & 10 \\
\hline
\end{tabular}

Source: FAN and field survey 


\section{Consumer}

The increase in demand from the past decade indicates the increase in number of consumers. Due to the modernization, the use of cut-flower has increased. Today flowers are being used widely in every traditional, religious-rituals, celebrations and ceremonies. The institutional buyers such as hotels and banks dominate the demand but their demand has remained constant from yesteryears (Figure: 4 and Table: 5). It is the local people that have created increase in demand.

Table 5: Present situation of consumer

\begin{tabular}{|l|l|}
\hline Constant in demand & Increment in demand \\
\hline $\begin{array}{l}\text { Officials, Foreign diplomatic mission, } \\
\text { Hotels, Restaurants }\end{array}$ & $\begin{array}{l}\text { Wedding receptions, conferences, festivals, } \\
\text { traditional and various occasions like birth, } \\
\text { death, welcome, farewell and other events } \\
\text { such as valentine's day and friendship day }\end{array}$ \\
\hline
\end{tabular}

Source: Field survey

Figure 4: Consumers in market

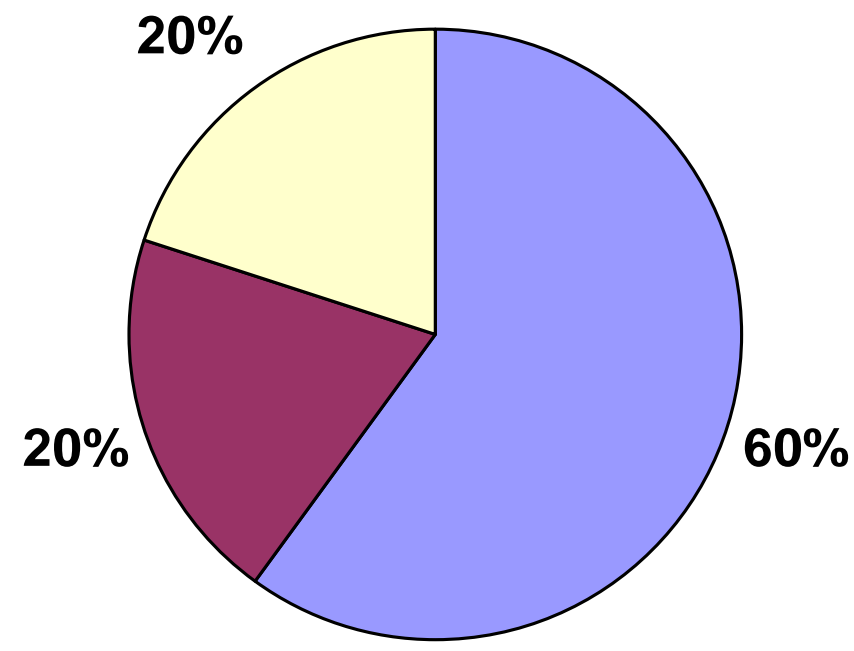

Source: Field Survey 


\section{Import}

Nepal imports floricultural products and its related goods from UK, France, the Netherlands, Japan, Thailand, Italy and India. The products include live trees and other plants; hybrid seeds, bulbs, roots, ornamental foliage and cut flowers. Cut flower is imported from Thailand, Italy and India (Table: 6). Most of the cut flower comes from India during winter season. The need of import has risen due to the lack of use of modern technology. But from past decade, due to the systematic production of cut flower, import has reduced to some extent.

Table 6: Cut flower imports

\begin{tabular}{|l|l|l|l|l|l|}
\hline Imports (year) & $\mathbf{2 0 0 2 / 0 3}$ & $\mathbf{2 0 0 3 / 0 4}$ & $\mathbf{2 0 0 4 / 0 5}$ & $\mathbf{2 0 0 5 / 0 6}$ & $\mathbf{2 0 0 6 / 0 7}$ \\
\hline $\begin{array}{l}\text { Total Imports } \\
\text { (NRs) }\end{array}$ & 52965298354 & 53234748492 & 55013729726 & 48086833230 & 79936111560 \\
\hline $\begin{array}{l}\text { Live trees and } \\
\text { other plants (NRs) }\end{array}$ & 393377 & 1338282 & 239707 & 159385 & 531817 \\
\hline Cut flower (NRs) & 147508 & 425865 & 131782 & 7875 & 167637 \\
\hline
\end{tabular}

Source: Trade Export Promoting Centre

\section{Export}

Nepal has capacity to export cut flowers. But, still there are a few floriculture organizations which export to other countries. Among them, Everest Floriculture exports Roses to Japan. There are some of them which export cut flowers to India occasionally, but in negligible amount (Table: 7). As compared to imports, the export in terms of value has significantly increasing each year.

Table 7: Cut flower exports in Asian market

\begin{tabular}{|l|l|l|l|l|l|}
\hline Exports (year) & $2002 / 03$ & $2003 / 04$ & $2004 / 05$ & $2005 / 06$ & $2006 / 07$ \\
\hline $\begin{array}{l}\text { Total Imports } \\
\text { (NRs) }\end{array}$ & 21981474737 & 20941661111 & 17691884708 & 18277759101 & 17198296949 \\
\hline $\begin{array}{l}\text { Live trees and } \\
\text { other plants (NR) }\end{array}$ & 18259383 & 11204703 & 16228315 & 32634275 & 20844930 \\
\hline Cut flower (NRs) & 4175826 & & & 35405 & 13177 \\
\hline
\end{tabular}

Source: Trade Export Promoting Centre 


\section{MARKET CHANNEL IN NEPAL}

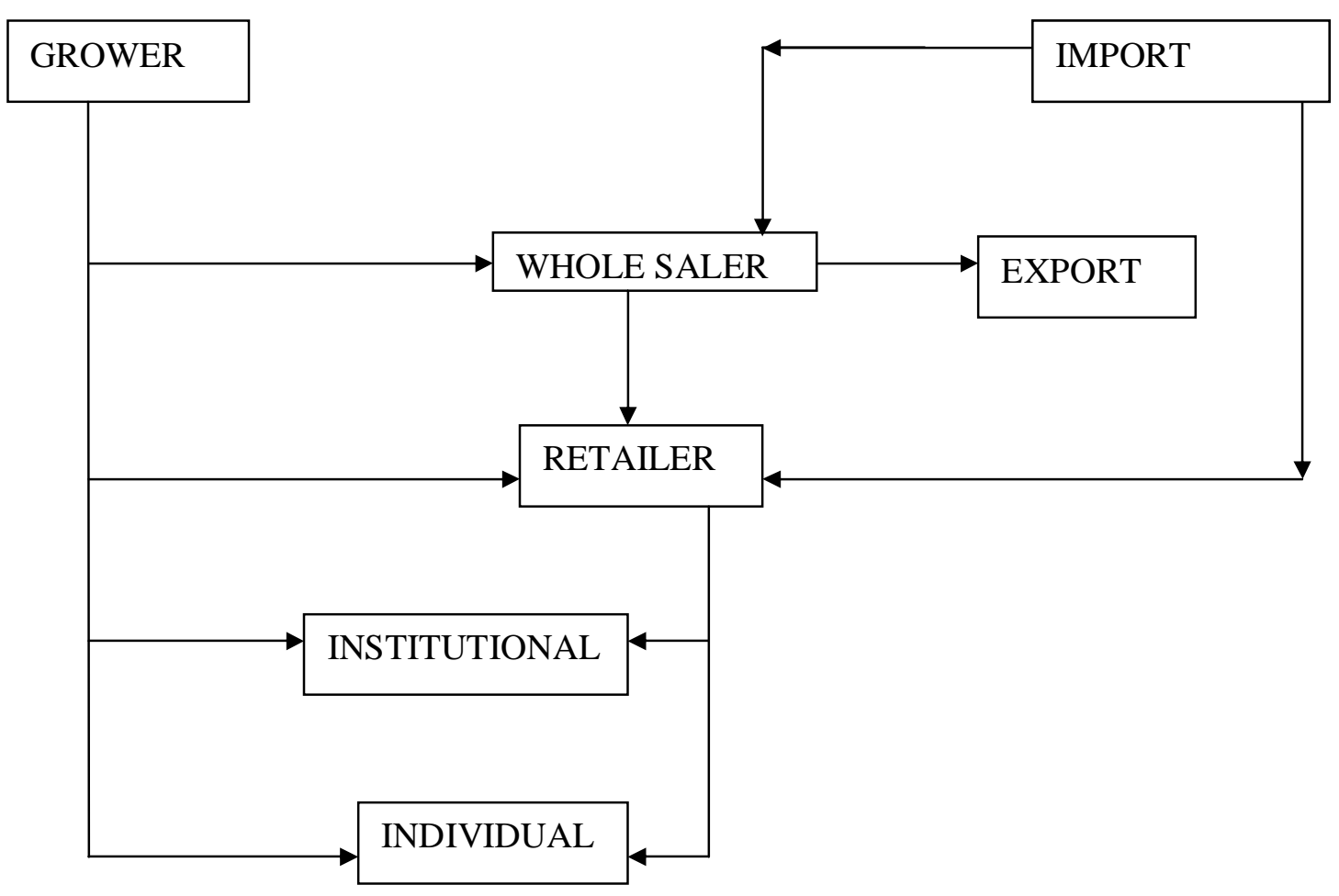

\section{CONCLUSIONS}

Nepal has a tremendous potential in the cut flowers business. Nepal is inefficient to produce the cut flower to fulfill the regular market demands. The public sector and government have to go a long way for the development of floriculture. Even though seasonal demands of the Nepali flowers are fulfilled by domestic production itself, during off-season they are compelled to import flowers from other countries. However, , Nepali flower industry is unpredictable because of uncontrolled hold of nurseries in Nepalese market.

\section{RECOMMENDATIONS}

1. The government should make the policy to encourage the farmers. They should provide subsidies on air freight, provide loans, decrease the interest rates and provide the market to domestic products.

2. The government and private sector should coordinate to initiate the hybrid seed production, and proper research on diseases and pests.

3. There should be construction of cooling storage at international airport and wholesale markets in other districts also.

4. Retailers complain about the lack of skilled manpower for the preservation of cut flower and decoration of the bouquet. Government organizations, agricultural institutes and private floriculture companies must spare some fund for research 
and development and train the human resources to strengthen floriculture business.

5. Technical knowledge related to post harvest handling, packaging, quality maintenance and preservation of flower has to be imparted to flower growers through the medium of training, conferences and seminars by qualified government personnel.

6. Foreign collaboration should be initiated as it can contribute a lot with respect to technical know-how, capital and market knowledge. The government through industrial policy must provide proper incentive package to foreign investors.

7. Quarantine law should be strictly employed during the import of planting materials from India and other countries.

\section{ACKNOWLEDGEMENT}

We are grateful to FAN (Floriculture Association of Nepal), AEC (Agro- Enterprises Centre), TEPC (Trade Promoting Centre), Flora-United, Flora Incorporated of Nepal, Flora Nepal Pvt. Ltd., The Standard Nursery, Design's Fresh Flower Shoppe, Design's Fresh Flower Shoppe, Chameli Nursery, Women in Floriculture, Bagmati Flora Pvt. Ltd., Daffodils Flowers shop, Florists and Kumari Flora for providing information during our field survey. We thank Mr. Hemraj Kafle for giving valuable suggestions during manuscript preparation.

\section{REFERENCES}

1. Anonymous, 2002. Flower Marketing in Kathmandu Valley. Ministry of Agriculture and Cooperatives, Kathmandu, Nepal.

2. Chhetri, B. 1999. Status of floriculture in Kathmandu: Role of tissue culture. Master thesis, Kathmandu University School of Science.

3. Devtec Nepal 1995. Business Plan for Cut Flower Gladiolus. Devtec Pvt. Ltd. Kathmandu, Nepal

4. Floriculture Association of Nepal 2007, 'Floriculture Trade Fair. Kathmandu, Nepal.

5. Floriculture Association of Nepal 2008. Floriculture Trade Fair. Kathmandu, Nepal.

6. Prasad, S. and Kumar, U. 2005. Commercial floriculture. Agribios (India), Jodhpur, pp.4-5

7. Shrestha, A., Shrestha, D., and Joshi, S. D. 1999. Cut Flower Business in NepalPerformance and Prospects. Master thesis, Kathmandu University School of Management.

\section{Organizations}

- FAN (Floriculture Association of Nepal)

- AEC (Agro- Enterprises Centre)

- TEPC (Trade Promoting Centre)

\section{Wholesalers}

- Flora-United

- Flora Incorporated of Nepal

- Flora Nepal Pvt. Ltd.

- The Standard Nursery 
KATHMANDU UNIVERSITY JOURNAL OF SCIENCE, ENGINEERING AND TECHNOLOGY

VOL. 5, No. I, JANUARY, 2009, pp 87- 98.

\section{Retailer}

- Design's Fresh Flower Shoppe

- Design's Fresh Flower Shoppe

- Chameli Nursery

- Women in Floriculture

- Bagmati Flora Pvt. Ltd.

- Daffodils Flowers shop

- Florists

- Kumari Flora 